\title{
THE TENSILE STRENGTH OF SOLID-STATE BONDED ALUMINUM AND NICKEL-PLATED URANIUM
}

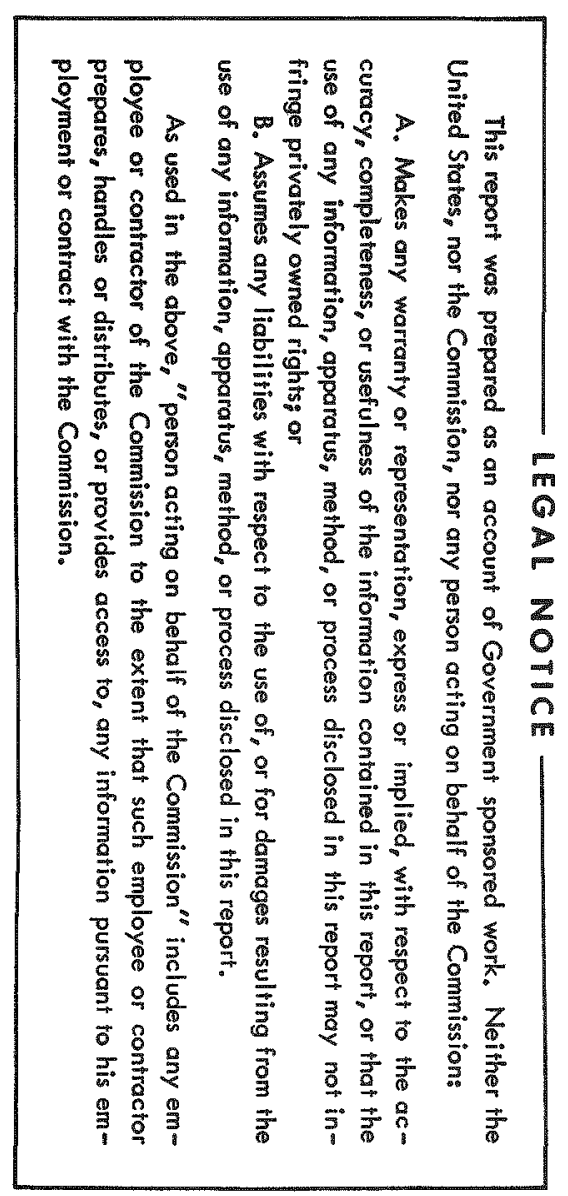

by

H. A. Saller

R. F. Dickerson

R. J. Carlson

October 21, 1954

\begin{tabular}{|l|}
\hline Photostat Price $\$ 3.30$ \\
Microfilm Price $\$ 2.40$ \\
Available from the \\
Office of Technical Services \\
Department of Commerce \\
Washington 25, D. C.
\end{tabular}

BATTELLE MEMORIAL INSTITUTE

505 King Avenue

Columbus I, Ohio

$900 \quad 0 \%$ 


\section{DISCLAIMER}

This report was prepared as an account of work sponsored by an agency of the United States Government. Neither the United States Government nor any agency Thereof, nor any of their employees, makes any warranty, express or implied, or assumes any legal liability or responsibility for the accuracy, completeness, or usefulness of any information, apparatus, product, or process disclosed, or represents that its use would not infringe privately owned rights. Reference herein to any specific commercial product, process, or service by trade name, trademark, manufacturer, or otherwise does not necessarily constitute or imply its endorsement, recommendation, or favoring by the United States Government or any agency thereof. The views and opinions of authors expressed herein do not necessarily state or reflect those of the United States Government or any agency thereof. 


\section{DISCLAIMER}

Portions of this document may be illegible in electronic image products. Images are produced from the best available original document. 
TABLE OF CONTENTS

Page

ABSTRAC $\cdot \cdot$

$\cdot \cdot$

INT RODUCTION

PRODUCTION OF TENSILE SPECIMENS

Equipment

Materials

Specimen Configuration and Size.

Specimen Preparation

General Pressing Procedures.

RESULTS OF TENSILE TESTS .

Effect of Bonding Temperature and Pressure . . . . 16 Effect of Variations in Anodic Activation and

Strike-Current Density . . . . . . . . . . 16

Effect of Bonding Time . . . . . . . . . . 20

Effect of Nickel Plating Both Components . . . . . 20

CONCLUSIONS • . . . . . . . . . . . . . . 23 


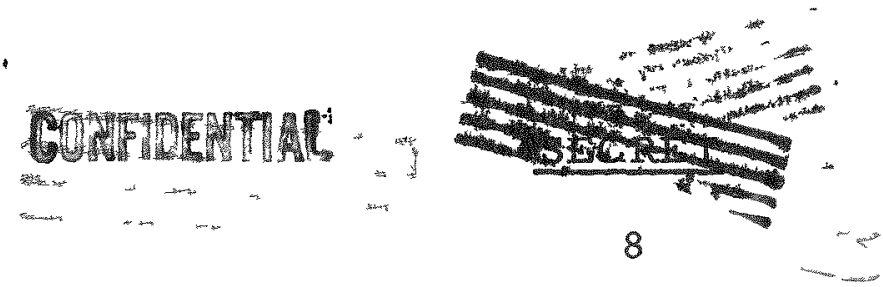

PRODUCTION OF TENSILE SPECIMENS

\section{Equipment}

The equipment used to produce tensile specimens consisted of a 20,000-lb-capacity laboratory-type press, a Chromel A resistance-wound vertical-muffle-type furnace and a die of the type shown in Figure 1. Airhardening die steel was used for the die. Because the total pressures involved were low, the pressure gage on the press was replaced with a $0-$ to $-500-1 b$ Bourdon gage.

Figures 2 and 3 depict the equipment components disassembled and assembled, respectively.

Power was supplied by a Variac $V-20-M$ autotransformer and temperatures were measured by means of a Chromel-Alumel thermocouple and a portable potentiometer.

\section{Materials}

The uranium components of the tensile specimens were fabricated from production-grade uranium by rolling, swaging, and drawing. The aluminum components were cut from 1/4-in.-diameter 2 s aluminum rod.

\section{Specimen Configuration and Size}

Figure 1 shows the aluminum and uranium components of a tensile specimen assembled in the die prior to pressing. The specimens were $1 / 4$ in. in diameter and each component was approximately $1-1 / 2 \mathrm{in}$. long.

A specimen length of 3 in. was chosen to minimize the distance through which the ram pressure had to be transmitted. The specimen diameter choosen, $1 / 4$ in., tended to give conservative values because of the greater sensitivity to microscopic defects.

\section{Specimen Preparation}

A general outline is given below for the preparation of the uranium and aluminum components of the tensile specimens. 


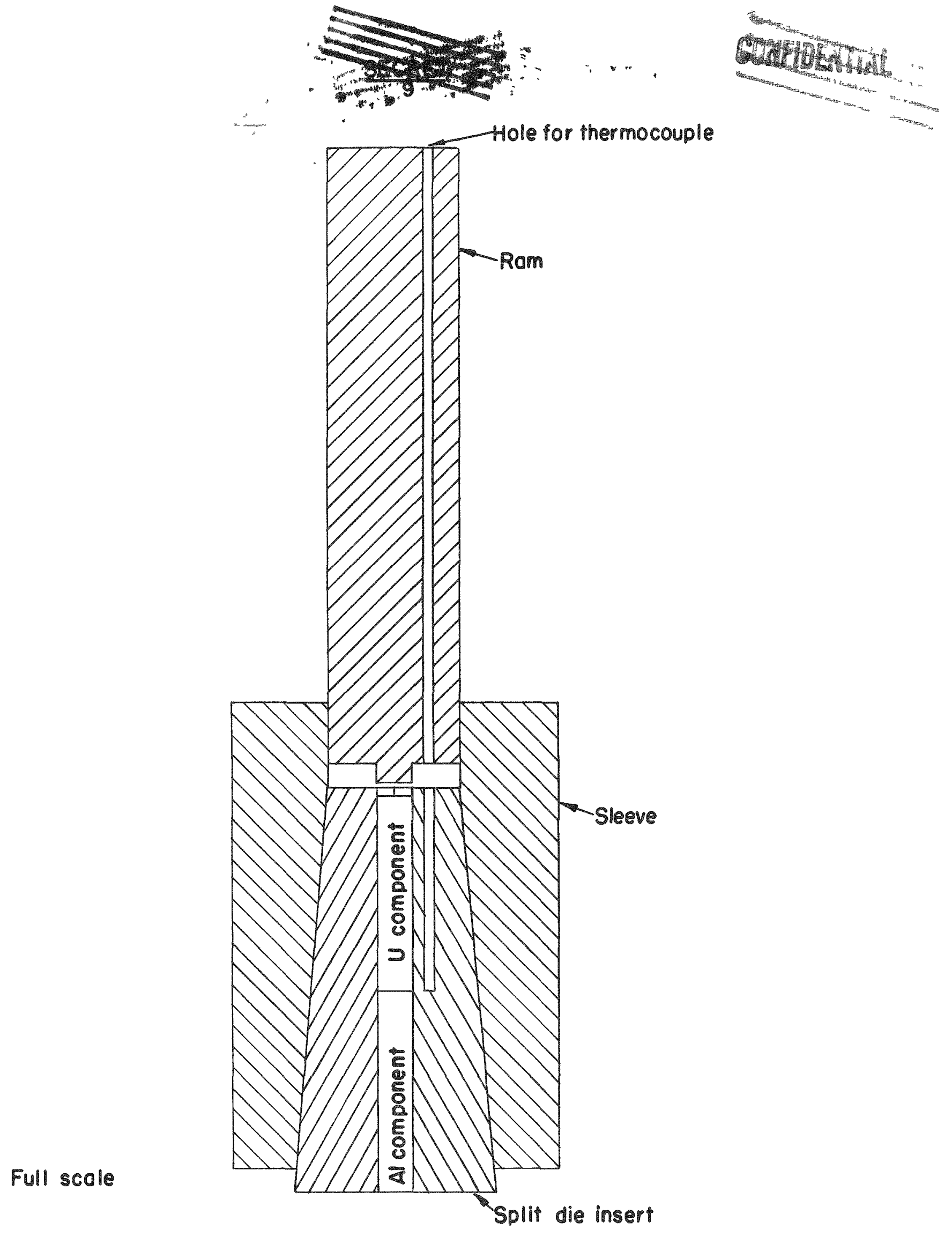

FIGURE I. CROSS SECTION OF DIE SHOWING ALUMINUM AND URANIUM COMPONENTS IN POSITION FOR PRESSING
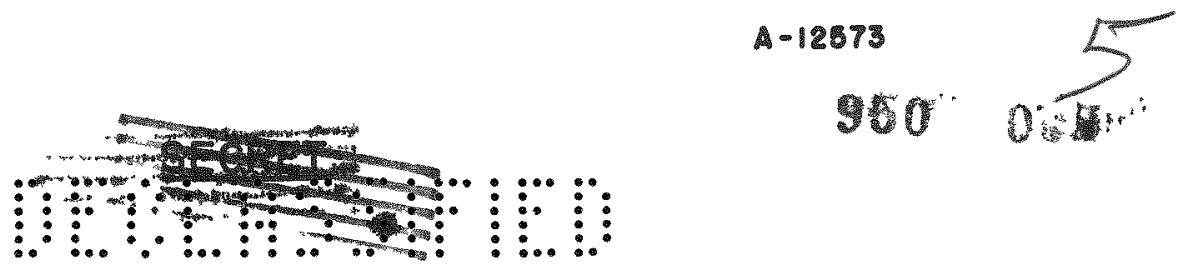

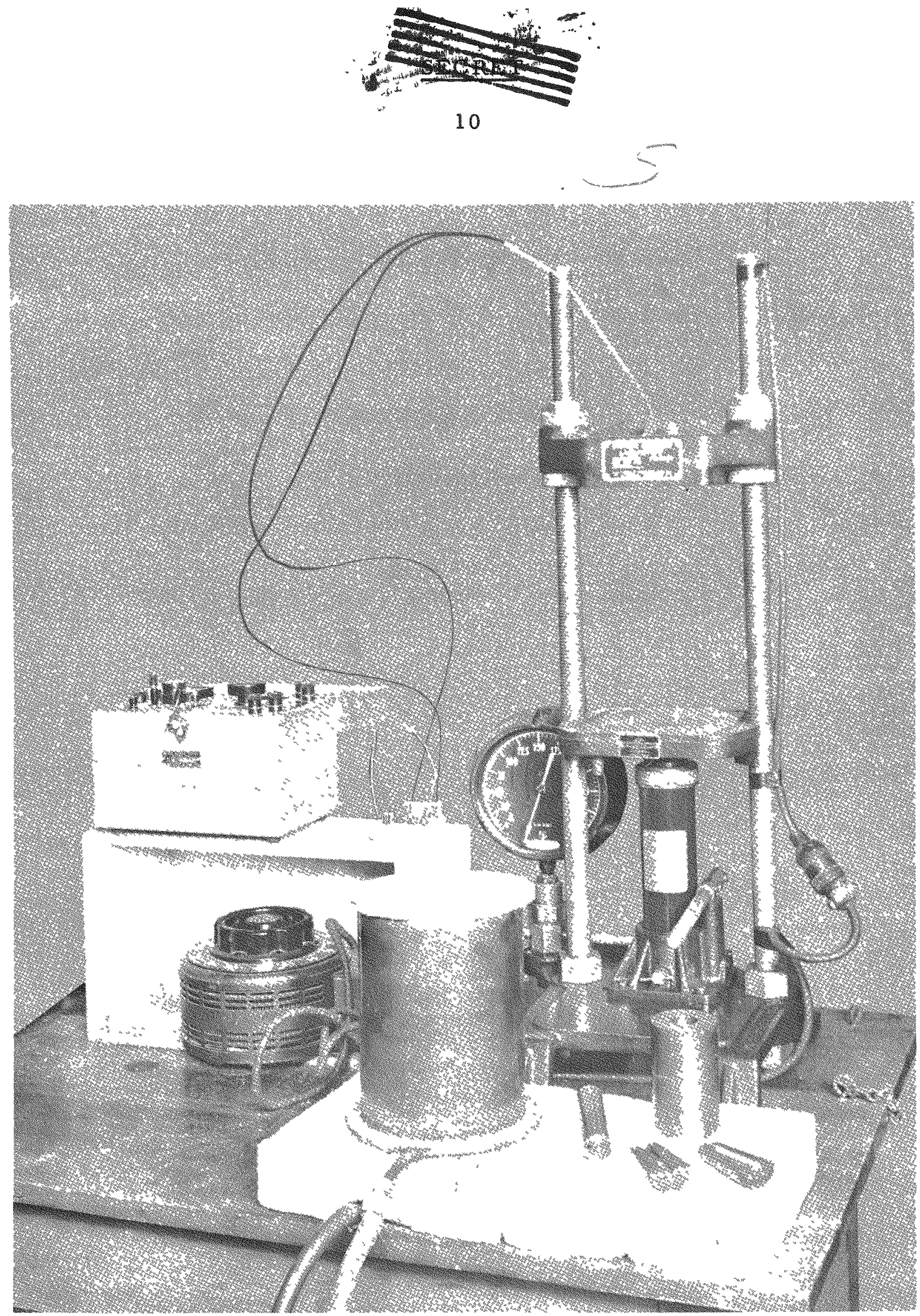

FIGURE 2. PHOTOGRAPH OF DISASSEMBLED EQUIPMENT COMPONENTS

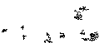

$950 \quad 66$

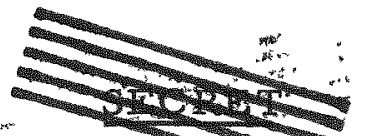




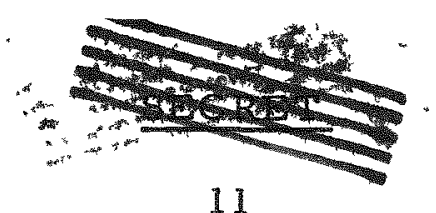

11

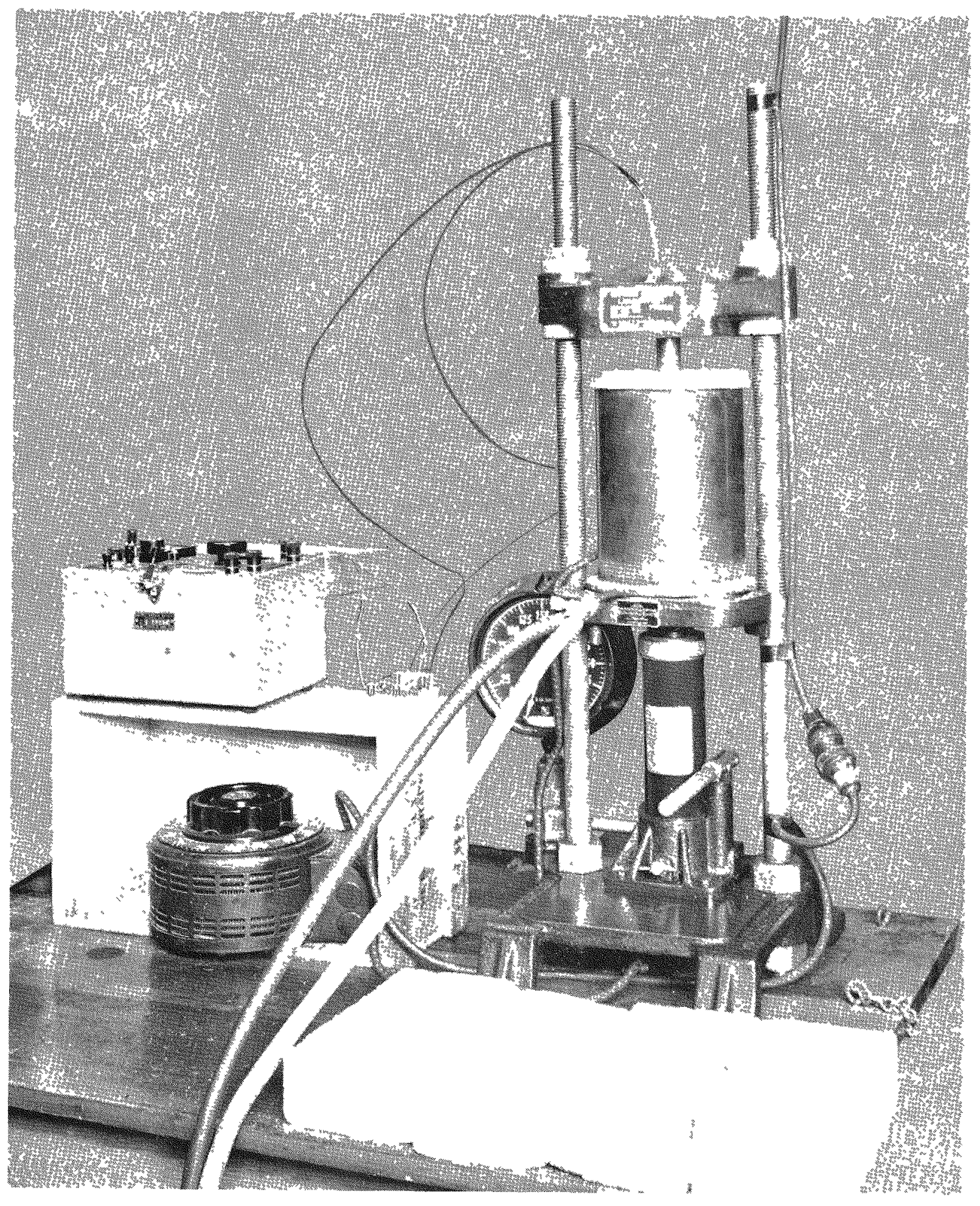

FIGURE 3. PHOTOGRAPH OF ASSEMBLED EQUIPMEN'L COMPONENTS

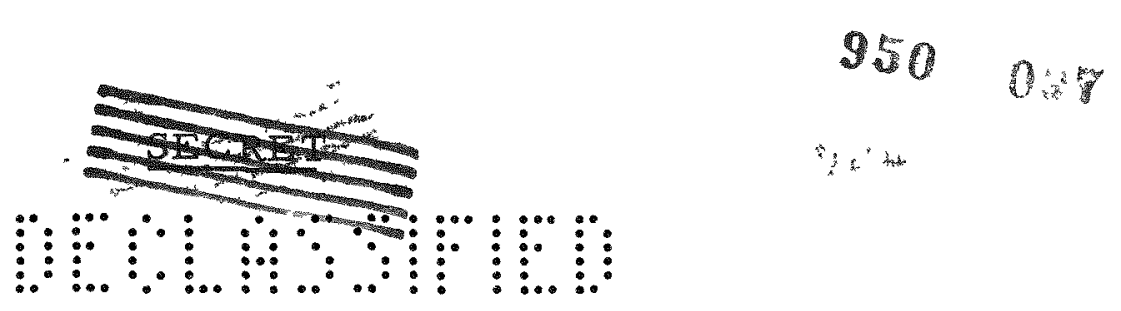




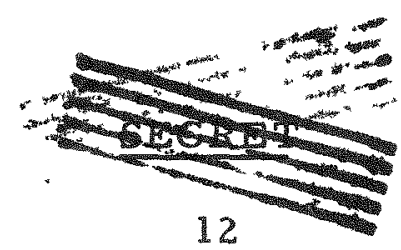

I. Preparation of Uranium Component

A. Mechanical preparation

1. Fabrication of the uranium to size and shape

2. Grit blasting of the uranium with $50-$ mesh crushed chilled steel shot at $80-1 b$ open-line pressure

B. Physical and chemical cleaning and activation

1. Degreasing in ethylene trichloride

2. Alkaline cleaning for $2 \mathrm{~min}$

3. Rinsing in water

4. Pickling in 1 -to- $1 \mathrm{HNO}_{3}$ and water

5. Rinsing in water

6. Anodic-etch activating in the following solution for $40 \mathrm{~min}$ at 25 amp per sq ft at $100 \mathrm{~F}$ :

50 volume per cent $\mathrm{H}_{3} \mathrm{PO}_{4}$ (85 per cent)

2 volume per cent HCI ( 38 per cent)

48 volume per cent $\mathrm{H}_{2} \mathrm{O}$

7. Adding of current robber

8. Rinsing in water

9. Pickling in 1 -to- $1 \mathrm{HNO}_{3}$ and water at $80 \mathrm{~F}$ for $5 \mathrm{~min}$

C. Electrodeposition of nickel, 0.0003 in. thick, from the following solution in $24 \mathrm{~min}$ at a current density of $15 \mathrm{amp}$ per sqft, a bath temperature of $100 \mathrm{~F}$, and a pH of 5.5:

$$
\mathrm{NiSO}_{4} \cdot 7 \mathrm{H}_{2} \mathrm{O} \quad 145 \mathrm{~g} \text { per liter }
$$

$\mathrm{MgSO}_{4} \cdot 7 \mathrm{H}_{2} \mathrm{O} \quad 75 \mathrm{~g}$ per liter

$$
\mathrm{NH}_{4} \mathrm{Cl} \quad 15 \mathrm{~g} \text { per liter }
$$

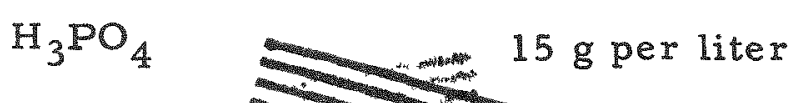




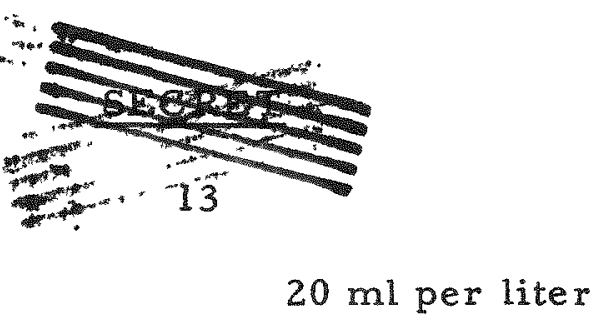

\section{Preparation of Aluminum Component}
A. Mechanical preparation of 1/4-in.-round 25 aluminum rod by cutting to length with a water-cooled cutoff wheel
B. Chemical cleaning by pickling 2 min in a 5 per cent aqueous solution of $\mathrm{NaOH}$ at $180 \mathrm{~F}$ and then pickling $5 \mathrm{~min}$ in $1-$ to-1 $\mathrm{HNO}_{3}$ and water at room temperature

\section{General Pressing Procedures}

The aluminum and uranium components and the die were assembled as shown in Figure 1. After assembly, the die was loaded into the furnace and the furnace was placed on the bottom die platen. A 50-1b preload was used to exclude all air from the bond interface during heating. The power to the furnace was turned off $25 \mathrm{~F}$ below the specimen's nominal pressing temperature and the full bonding load was applied. Thermal inertia of the die and furnace was sufficient to carry the specimen temperature $25 \mathrm{~F}$ above the nominal pressing temperature in about $2-1 / 2 \mathrm{~min}$. After $5 \mathrm{~min}$, the die and specimen were quenched in water.

A typical time-temperature curve for the 5-min period during which the specimen was under full bonding load is shown in Figure 4. Figure 5 shows a completed tensile specimen and Figure 6 a typical microstructure of the bond zone.

Variations from the above general procedures are indicated in the tables.

\section{RESULTS OF TENSILE TESTS}

The tensile specimens were pulled on a standard tensile-testing machine and standard procedures were used. Figure 7 illustrates the three principal types of specimen failure. Specimen A failed between the nickel and aluminum before any deformation was evident in the aluminum. This type of failure indicates either that bonding temperature and pressure were too low or that techniques were faulty.

Proprietary werting agent manufactured by the Harshaw Chemical Company.
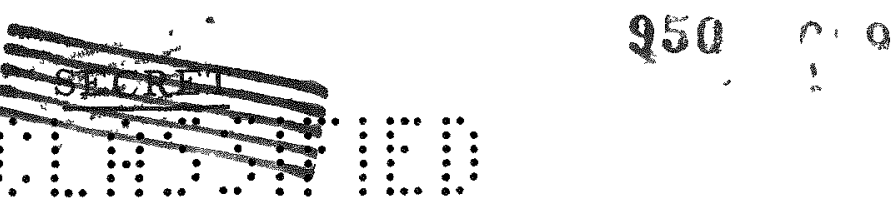



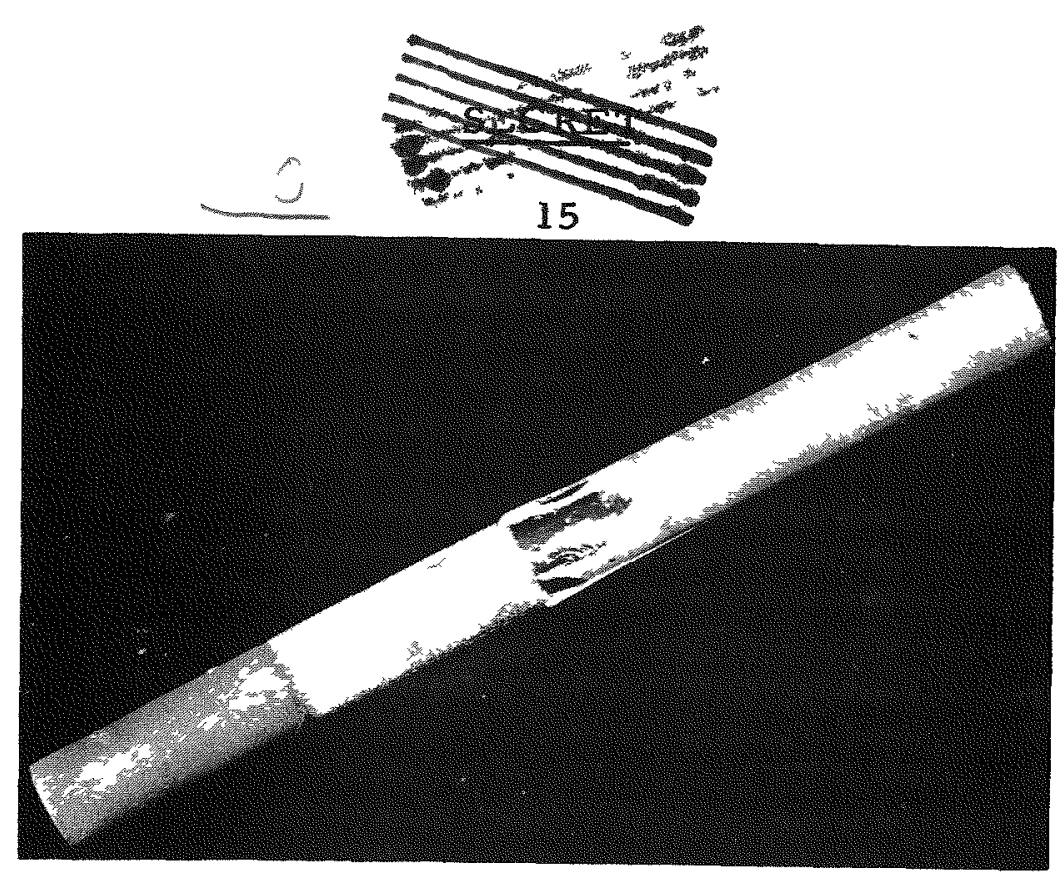

N17438

FIGURE 5. PHOTOGRAPH OF COMPLETED TENSILE SPECIMEN

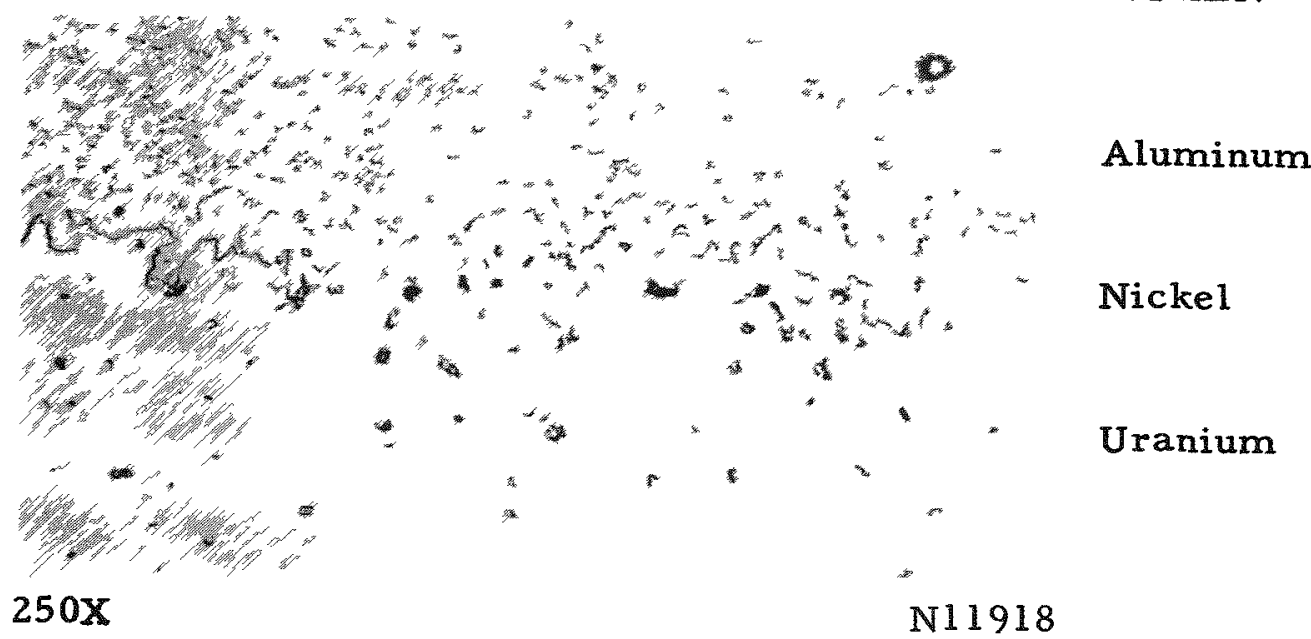

FIGURE 6. TYPICAL MICROSTRUCTURE OF BOND ZONE

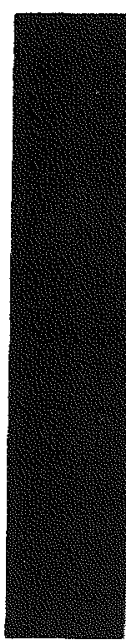

$2.25 \mathrm{X}$
A

B

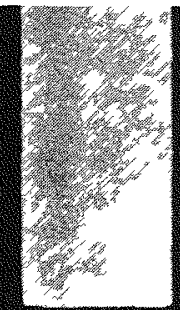

C

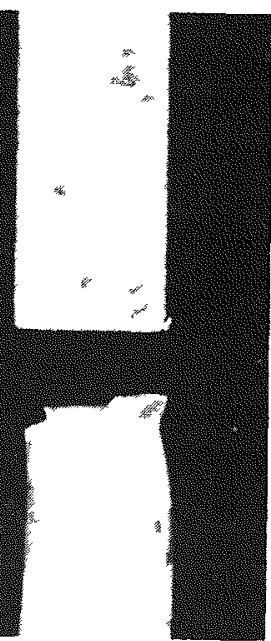

N16835

FIGURE 7. PHOTOGRAPH OF THREE PRINCIPAL TYPES OF SPECIMEN FAILURE

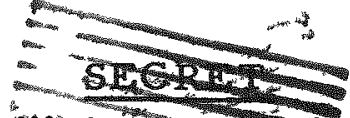




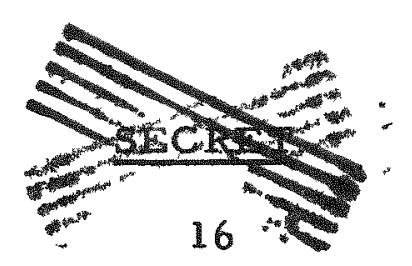

Specimen $B$ failed in the aluminum component, indicating that the tensile strength of the bond was at least as great as that of the aluminum.

Specimen $C$ also failed between the nickel and aluminum. In this case, however, appreciable deformation occurred in the aluminum near the bond interface. This deformation may have caused a change in direction of the forces at the interface and this may, in turn, have caused the failure at the bond. The tensile strengths of the bonds in specimens which failed in this manner were at least very near the yield strength of the aluminum.

A few specimens were made with high-alloy aluminum components instead of the usual 25 aluminum components. Such specimens failed between the nickel and uranium and had tensile strengths ranging from 18,000 to $30,000 \mathrm{psi}$. These results indicate that the nickel-uranium bond has a tensile strength of at least 18,000 psi.

\section{Effect of Bonding Temperature and Pressure}

The first series of specimens was designed to survey the effect of bonding temperatures and pressures. Temperatures were varied from 800 to $950 \mathrm{~F}$ and pressures were varied from 3000 to 6000 psi. Table 1 is a compilation of data from this series of experiments.

Tensile strengths indicated to the right and below the dotted line in Table 1 are equal to or greater than the yield strength of $2 \mathrm{~S}$ aluminum. In this range, variation of pressing pressure and temperature has little or no effect on the resulting tensile strength when 25 aluminum is used as one component of the diffusion couple.

Effect of Variations in Anodic Activation and StrikeCurrent Density

The second series of specimens was designed to determine the effect of variations in anodic activation prior to electroplating and the effect of strike-current density during electroplating. Relatively low bonding temperature and pressure, $850 \mathrm{~F}$ and $4000 \mathrm{psi}$, were chosen for this series because it was felt that these conditions would be more sensitive to the effects of variations in activation and strike-current density than higher bonding conditions would be. The data from this series of specimens are presented in Table 2.

$950 \quad 12$

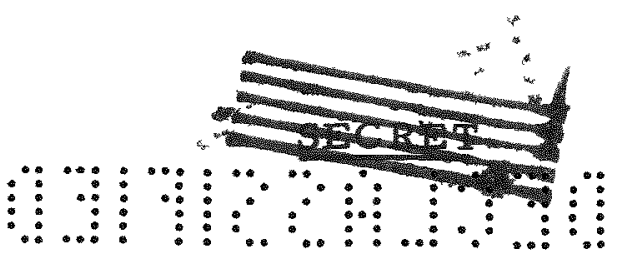


TABLE 1. EFFECT OF PRESSING PRESSURES AND TEMPERATURES ON TENSILE STRENGTH

\begin{tabular}{|c|c|c|c|c|}
\hline \multirow{2}{*}{$\begin{array}{c}\text { Pressing } \\
\text { Pressure, psi } \\
\end{array}$} & \multicolumn{4}{|c|}{ Tensile Strength, psi } \\
\hline & $800 \mathrm{~F}$ & $850 \mathrm{~F}$ & $900 \mathrm{E}$ & $950 \mathrm{~F}$ \\
\hline \multirow[t]{4}{*}{3000} & 3,240 & 1,600 & 4,600 & 9,100 \\
\hline & 3,540 & 4,000 & 6,400 & 8,300 \\
\hline & 1,120 & 5,900 & 3,800 & - \\
\hline & - & - & 5,200 & - \\
\hline \multirow[t]{5}{*}{4000} & 8,060 & 5,000 & 7,000 & 10,000 \\
\hline & 900 & 4,200 & 11,900 & 12,600 \\
\hline & - & 4,240 & 11,800 & 10,900 \\
\hline & - & 4,200 & - & 11,800 \\
\hline & - & 4,180 & - & 11,800 \\
\hline \multirow[t]{4}{*}{5000} & 3,700 & 4,600 & 7,400 & 10,800 \\
\hline & 4,280 & 4,800 & 7,700 & 12,600 \\
\hline & - & 5,400 & 7,000 & 11,100 \\
\hline & - & - & - & 7,920 \\
\hline \multirow[t]{5}{*}{6000} & 5,900 & 6,900 & 11,200 & 10,800 \\
\hline & 5,900 & 9,100 & 11,860 & 11,400 \\
\hline & 4,900 & 7,240 & 10,400 & - \\
\hline & - & - & 11,000 & - \\
\hline & - & - & 8,600 & - \\
\hline
\end{tabular}




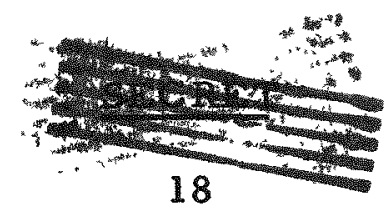

TABLE 2. EFFECT OF VARIATIONS IN ANODIC ON TENSILE STRENGTH ACTIVATION AND STRIKE-CURRENT DENSITY

\begin{tabular}{|c|c|c|c|c|c|}
\hline \multirow{2}{*}{$\begin{array}{l}\text { Activation } \\
\text { Current Density, } \\
\text { amp per sq ft } \\
\end{array}$} & \multirow{2}{*}{$\begin{array}{l}\text { Time, } \\
\min \\
\end{array}$} & \multicolumn{4}{|c|}{$\begin{array}{c}\text { Tensile Strength, psi, at Indicated } \\
\text { Strike-Current Density (a), amp per sq ft }\end{array}$} \\
\hline & & 120 & 60 & 30 & None \\
\hline \multirow[t]{3}{*}{25} & 10 & 700 & - & - & $\begin{array}{l}\text { Did not } \\
\text { bond }\end{array}$ \\
\hline & - & 3000 & - & - & $\begin{array}{l}\text { Did not } \\
\text { bond }\end{array}$ \\
\hline & - & 5800 & - & - & 6300 \\
\hline \multirow[t]{3}{*}{35} & 14 & - & $\begin{array}{l}\text { Did not } \\
\text { bond }\end{array}$ & 1900 & - \\
\hline & - & - & 800 & $\begin{array}{c}\text { Did not } \\
\text { bond }\end{array}$ & - \\
\hline & - & - & 2800 & 12,500 & - \\
\hline \multirow[t]{3}{*}{45} & 22 & - & $\begin{array}{l}\text { Did not } \\
\text { bond }\end{array}$ & 1600 & - \\
\hline & - & - & 4500 & 600 & - \\
\hline & - & - & 4300 & - & - \\
\hline \multirow[t]{3}{*}{25} & 60 & 1500 & - & - & 2840 \\
\hline & - & 600 & - & - & 8000 \\
\hline & - & 4000 & - & - & 6440 \\
\hline \multirow[t]{3}{*}{35} & 57 & - & 1100 & $\begin{array}{l}\text { Did not } \\
\text { bond }\end{array}$ & $t$ \\
\hline & - & - & 2000 & 6840 & - \\
\hline & - & - & 800 & 2700 & - \\
\hline \multirow[t]{3}{*}{45} & 56 & 6800 & - & - & 4400 \\
\hline & - & 5200 & - & - & 6100 \\
\hline & - & 8600 & - & - & 5100 \\
\hline
\end{tabular}




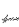

TABLE 2. (Continued)

\begin{tabular}{|c|c|c|c|c|c|}
\hline \multirow{2}{*}{$\begin{array}{c}\text { Activation } \\
\text { Current Density, } \\
\text { amp per sq ft }\end{array}$} & \multirow{2}{*}{$\begin{array}{c}\text { Time, } \\
\text { min } \\
\end{array}$} & \multicolumn{4}{|c|}{$\begin{array}{l}\text { Tensile Strength, psi, at Indicated } \\
\text { Strike-Current Density }(a) \text {, amp per sq ft }\end{array}$} \\
\hline & & 120 & 60 & 30 & None \\
\hline \multirow[t]{3}{*}{25} & 120 & 600 & - & - & $\begin{array}{l}\text { Did not } \\
\text { bond }\end{array}$ \\
\hline & - & 4600 & - & - & 6100 \\
\hline & - & 2900 & - & - & 4300 \\
\hline \multirow[t]{3}{*}{35} & 100 & - & $\begin{array}{l}\text { Did not } \\
\text { bond }\end{array}$ & 8700 & - \\
\hline & - & - & 1900 & 8240 & - \\
\hline & - & - & 5800 & 7200 & - \\
\hline
\end{tabular}

(a)Total calculated thickness of nickel is 0.0003 in. Total strike time is 30 sec. 


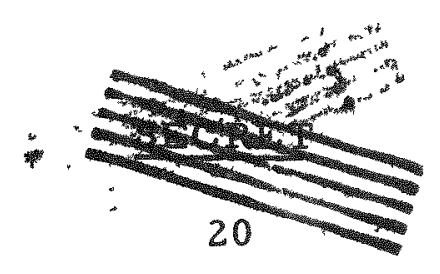

The results of this series of specimens were too erratic to show any trends with regard to the effect of variations in activation and strike-current density. However, these data may be regarded as further proof that a temperature of $850 \mathrm{~F}$ and a pressure of $4000 \mathrm{psi}$ is insufficient to yield reproducible bond strengths in times less than $5 \mathrm{~min}$.

The third series of tensile specimens was a repetition of the second, except that the specimens were bonded at a higher temperature and pressure ( $950 \mathrm{~F}$ and $6000 \mathrm{psi}$ ). Data from this series of specimens are shown in Table 3 .

The third series of specimens again failed to show any effect of strikecurrent density or variation in activation on tensile strength. On the contrary, this series of specimens indicated quite strongly that variations in strike-current density and activation within the limits used in this experiment have little or no effect on tensile strength.

\section{Effect of Bonding Time}

The fourth series of tensile specimens was designed to determine the effect of bonding time on tensile strength. These specimens were all bonded at $950 \mathrm{~F}$ and $6000 \mathrm{psi}$. The results of this series of tests are reported in Table 4.

This series of specimens illustrates clearly that any bonding time between $1 \mathrm{~min}$ and $5 \mathrm{~min}$ ( $5 \mathrm{~min}$ was used in previous experiments) will produce uniformly high tensile strengths. Except in the case of one specimen, even 30 sec yielded relatively high tensile strengths.

\section{Effect of Nickel Plating Both Components}

The fifth and final series of specimens was designed to compare the tensile strength of nickel-plated aluminum bonded to nickel-plated uranium with that of unplated aluminum bonded to nickel-plated uranium. The series consisted of five specimens with nickel-plated aluminum and one control specimen with unplated aluminum. All of the specimens were
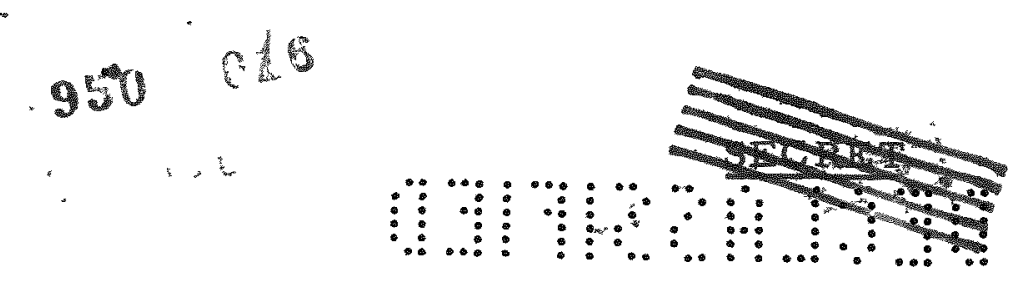
TABLE 3. EFEECT OF VARIATIONS IN ANODIC ACTIVATION AND STRIKE-CURRENT DENSITY ON TENSILE STRENGTH

\begin{tabular}{|c|c|c|c|c|c|}
\hline \multirow{2}{*}{$\begin{array}{c}\text { Activation } \\
\text { Current Density, } \\
\text { amp per sq ft }\end{array}$} & \multirow{2}{*}{$\begin{array}{l}\text { Time, } \\
\text { min }\end{array}$} & \multicolumn{4}{|c|}{$\begin{array}{c}\text { Tensile Strength, psi, at Indicated } \\
\text { Strike-Current Density (a), amp per sq ft }\end{array}$} \\
\hline & & 120 & 60 & 30 & None \\
\hline \multirow[t]{3}{*}{25} & 10 & 12,200 & - & - & 12,400 \\
\hline & - & 12,300 & - & - & 12,500 \\
\hline & - & 12,600 & - & - & 12,400 \\
\hline \multirow[t]{3}{*}{35} & 14 & - & 11,800 & 12,500 & - \\
\hline & - & - & 12,500 & 12,600 & - \\
\hline & - & - & 12,600 & 12,800 & - \\
\hline \multirow[t]{3}{*}{45} & 22 & - & 12,300 & 11,300 & - \\
\hline & - & - & 12,400 & 5,400 & - \\
\hline & - & - & 12,400 & 12,500 & - \\
\hline \multirow[t]{3}{*}{25} & 60 & 12,400 & - & - & 12,300 \\
\hline & - & 11,800 & - & - & 12,400 \\
\hline & - & 11,800 & - & - & 12,600 \\
\hline \multirow[t]{3}{*}{35} & 57 & - & 12,300 & 12,400 & - \\
\hline & - & - & 12,400 & 12,100 & - \\
\hline & - & - & 11,400 & 11,500 & - \\
\hline \multirow[t]{3}{*}{45} & 56 & 12,600 & - & - & 10,200 \\
\hline & - & 12,200 & - & - & 11,200 \\
\hline & - & 12,500 & - & - & 11,300 \\
\hline \multirow[t]{3}{*}{25} & 120 & 12,400 & - & - & 12,400 \\
\hline & - & 12,400 & - & - & 11,300 \\
\hline & - & 10,300 & - & - & 12,200 \\
\hline \multirow[t]{3}{*}{35} & 100 & - & 11,700 & 12,600 & - \\
\hline & - & - & 11,900 & 12,700 & - \\
\hline & - & - & 12,400 & 10,700 & - \\
\hline
\end{tabular}

(a)Total calculated thickness of nickel is $0.0003 \mathrm{in}$. Total strike tume is $30 \mathrm{sec}$.

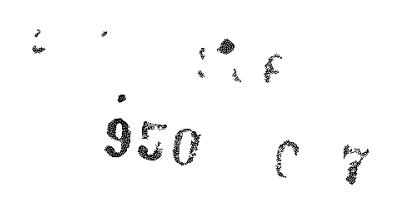




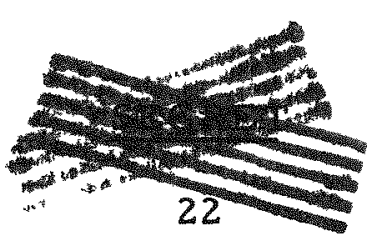

TABLE 4. EFFECT OF BONDING TIME ON TENSILE STRENGTH

\begin{tabular}{|c|c|}
\hline Bonding Time, $\min$ & Tensile Strength, psi \\
\hline \multirow[t]{5}{*}{4} & 12,400 \\
\hline & 11,000 \\
\hline & 12,700 \\
\hline & 12,700 \\
\hline & 10,800 \\
\hline \multirow[t]{5}{*}{3} & 12,800 \\
\hline & 8,700 \\
\hline & 12,400 \\
\hline & 12,800 \\
\hline & 12,800 \\
\hline \multirow[t]{4}{*}{2} & 10,000 \\
\hline & 9,800 \\
\hline & 12,900 \\
\hline & 12,800 \\
\hline \multirow[t]{6}{*}{1} & 12,800 \\
\hline & 12,900 \\
\hline & 12,700 \\
\hline & 12,500 \\
\hline & 11,200 \\
\hline & 12,900 \\
\hline \multirow[t]{5}{*}{0.5} & 10,700 \\
\hline & 12,400 \\
\hline & 10,200 \\
\hline & 12,100 \\
\hline & 5,300 \\
\hline
\end{tabular}

$950 \quad 018$ 


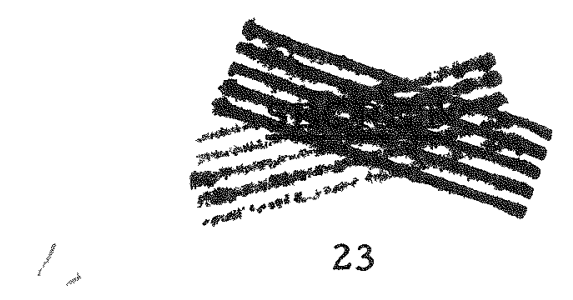

bonded at $950 \mathrm{~F}$ and $6000 \mathrm{psi}$ for $5 \mathrm{~min}$. Table 5 is a compilation of data from this series.

TABLE 5. EFFECT OF NICKEL PLATING BOTH

COMPONENTS ON TENSILE STRENGTH

\begin{tabular}{lc}
\hline \multicolumn{1}{c}{ Specimen } & Tensile Strength, psi \\
\hline Nickel-plated aluminum & 7,300 \\
Nickel-plated aluminum & 6,800 \\
Nickel-plated aluminum & 7,700 \\
Nickel-plated aluminum & 7,700 \\
Nickel-plated aluminum & 7,200 \\
& \\
Unplated aluminum & 12,400 \\
\end{tabular}

From this series of specimens it may be deduced that, at least as far as tensile strength is concerned, it is a decided disadvantage to use nickel-plated aluminum in conjunction with nickel-plated uranium in solidstate bonding work.

The tensile strengths recorded in Tables 1 through 5 were limited by the tensile strength of $2 \mathrm{~S}$ aluminum. It is quite possible that, when aluminum alloys, instead of 25 aluminum, are used with nickel-plated uranium in solid-state bonding work, pressing conditions other than those indicated above might prove advantageous.

\section{CONCLUSIONS}

This study of the tensile strengths obtained in tensile-strength testing of the bond between aluminum and nickel-plated uranium leads to the following general conclusions.

(1) Bonding temperature must be at least $950 \mathrm{~F}$ if the bonding pressure is 5000 psi or less. At 6000 psi, $900 \mathrm{~F}$ will produce uniformly strong bonds.
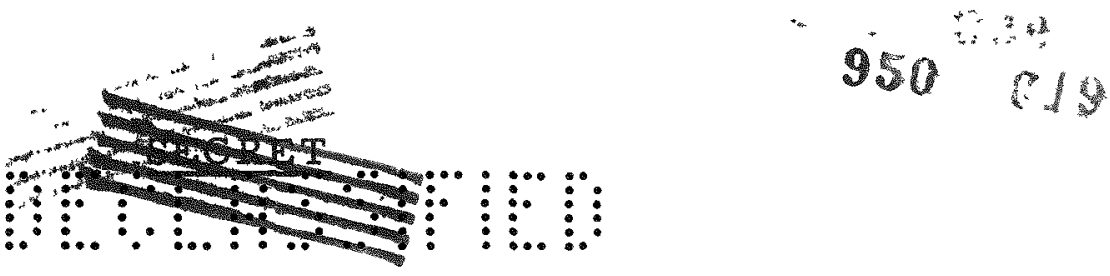


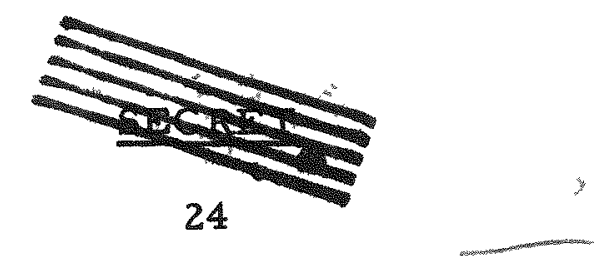

(2) Bonding pressures must be at least 4000 psi to yield uniformly high tensile values at $950 \mathrm{~F}$.

(3) Bonding times of 1 min or more are satisfactory.

(4) Anodic activation and strike-current density are not critical if required minimum bonding temperature and pressure are maintained.

(5) Nickel plating of the aluminum component as well as the uranium component substantially reduces the tensile strength of the resulting bond.

HAS/RFD/RJC :bk

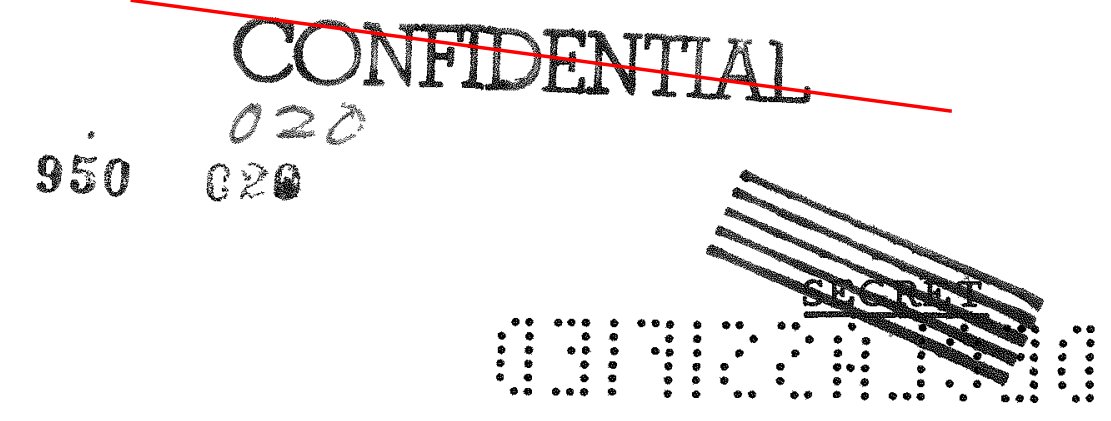

